\title{
EVALUASI KUALITAS UDARA STUDI KASUS 3 LOKASI PUSKESMAS DI KOTA CIMAHI PROVINSI JAWA BARAT
}

\author{
Ida Munfarida \\ Program Studi Teknik Lingkungan, Fakultas Sains dan Teknologi, UIN Sunan Ampel Surabaya \\ Email: munfarida@uinsby.ac.id
}

\begin{abstract}
ABSTRAK
Pencemar udara dapat berupa gas yang terdiri dari nitrogen oksida $\left(\mathrm{NO}, \mathrm{NO}_{2}\right)$, sulfur oksida $\left(\mathrm{SO}, \mathrm{SO}_{2}\right)$, karbon monoksida $(\mathrm{CO})$, oksidan $\left(\mathrm{O}_{3}\right)$, gas volatil yang tersebar ke udara. dan berupa debu (TSP) atau partikulat. Pencemar udara telah terbukti berdampak negatif pada kesehatan manusia, tumbuhan dan lingkungan. Pencemar udara diketahui dihasilkan dari berbagai sektor antara lain sektor industri, permukiman, perkantoran, dan transportasi. Sektor pelayanan publik seperti Puskesmas merupakan sarana kesehatan yang memiliki peranan vital sebagai tempat pertama upaya penyembuhan penyakit. Maksud dari penelitian ini adalah untuk mengevaluasi kualitas udara di 3 lokasi Puskesmas di Kota Cimahi Provinsi Jawa Barat dengan tujuan adalah menguji parameter kualitas udara meliputi gas dan partikulat yakni nitrogen dioksida $\left(\mathrm{NO}_{2}\right)$, sulfur dioksida $\left(\mathrm{SO}_{2}\right)$, karbon monoksida $(\mathrm{CO})$, oksidan $\left(\mathrm{O}_{3}\right)$, dan partikulat (TSP) serta menganalisa tingkat pencemar udara di 3 lokasi Puskesmas di Kota Cimahi Provinsi Jawa Barat. Metode penelitian dengan cara pengukuran kualitas udara langsung di lokasi penelitan bekerja sama dengan PDAM Tirta Wening Kota Bandung. Parameter kualitas udara yang diukur meliputi gas dan partikulat yakni nitrogen dioksida $\left(\mathrm{NO}_{2}\right)$, sulfur dioksida $\left(\mathrm{SO}_{2}\right)$, karbon monoksida $(\mathrm{CO})$, oksidan $\left(\mathrm{O}_{3}\right)$, dan partikulat (TSP). Pengukuran dilakukan pada waktu siang hari sebanyak satu kali pengukuran. Pengukuran nitrogen dioksida $\left(\mathrm{NO}_{2}\right)$, sulfur dioksida $\left(\mathrm{SO}_{2}\right)$, oksidan $\left(\mathrm{O}_{3}\right)$, dan partikulat (TSP) menggunakan peralatan tabung dan impinger, sementara untuk karbon monoksida (CO) menggunakan $\mathrm{CO}$ Analyzer dengan metode direct reading. Hasil penelitian menunjukkan bahwa semua parameter udara gas dan partikulat yang diuji yakni nitrogen dioksida $\left(\mathrm{NO}_{2}\right)$, sulfur dioksida $\left(\mathrm{SO}_{2}\right)$, karbon monoksida $(\mathrm{CO})$, oksidan $\left(\mathrm{O}_{3}\right)$, dan partikulat (TSP) pada 3 lokasi Puskesmas di Kota Cimahi masih memenuhi baku mutu udara ambien berdasarkan Peraturan Pemerintah No. 41 Tahun 1999 tentang pengendalian pencemaran udara. Hal ini membuktikan bahwa kondisi udara di 3 lokasi Puskesmas di Kota Cimahi memenuhi kualitas mutu sehingga dapat mendukung Puskesmas dalam upaya menjalankan fungsi penyembuhan penyakit dan pemulihan kesehatan dengan baik.
\end{abstract}

Kata kunci : Pencemar Udara, Gas, Partikulat, Puskesmas.

\section{PENDAHULUAN}

\section{Latar Belakang}

Udara merupakan salah satu media lingkungan yang merupakan kebutuhan dasar manusia sehingga udara yang berkualitas menjadi syarat penting dalam kehidupan. Berbagai penelitian terdahulu telah banyak dibuktikan bahwa saat ini telah terjadi pencemaran di seluruh dunia, termasuk kawasan Asia (Vadveru, dkk, 2014). Pencemar udara dapat berupa gas yakni nitrogen oksida $\left(\mathrm{NO}, \mathrm{NO}_{2}\right)$, sulfur oksida $\left(\mathrm{SO}, \mathrm{SO}_{2}\right)$, karbon monoksida $(\mathrm{CO})$, oksidan $\left(\mathrm{O}_{3}\right)$, Timbal ( $\mathrm{Pb}$ ), gas volatil yang tersebar ke udara dan berupa debu (TSP) atau partikulat (Soedomo, 2001). Pencemar udara telah terbukti berdampak negatif pada kesehatan manusia, tumbuhan dan lingkungan. Penelitian-penelitian terdahulu telah membuktikan adanya dampak negatif pencemar udara terhadap kesehatan manusia, seperti penyakit yang berhubungan dengan pernafasan, tingkat kematian yang tinggi, hingga kunjungan pasien ke rumah sakit yang meningkat akibat paparan pencemar udara (Dockery dkk., 1994; Lee dkk., 2000; Schwartz, 1999; Yang dkk., 2004; Tao dkk, 2015). Dampak negatif pencemar udara terhadap tanaman juga terlihat baik secara morfologi maupun 
fisiologi (Gostin, 2009; Agrawal dkk, 2003; Cape, 2003). Dampak negatif pencemar udara terhadap lingkungan terutama meningkatkan efek gas rumah kaca yang hingga saat ini menjadi perhatian dunia (Vadveru, dkk, 2014).

Pencemar udara diketahui dihasilkan dari berbagai sektor antara lain sektor industri, permukiman, perkantoran, dan transportasi (Chan dkk, 2002). Sektor pelayanan publik seperti puskesmas merupakan sarana kesehatan yang memiliki peranan vital sebagai tempat pertama upaya penyembuhan penyakit. Berdasarkan SK Menteri Kesehatan No. 582/MENKES/SK/VI/1997 menyebutkan bahwa Puskesmas adalah sarana kesehatan yang menyelenggarakan kesehatan secara merata dengan mengutamakan penyembuhan penyakit dan pemulihan kesehatan. Untuk itu, kualitas udara di Puskesmas merupakan faktor penting demi terselenggaranya upaya penyembuhan penyakit dan pemulihan kesehatan.

Dalam penelitian ini, dievaluasi kualitas udara di 3 lokasi Puskesmas di Kota Cimahi Jawa Barat yakni Puskesmas Melong Asih, Puskesmas Melong Tengah dan Puskesmas Cimahi Selatan.

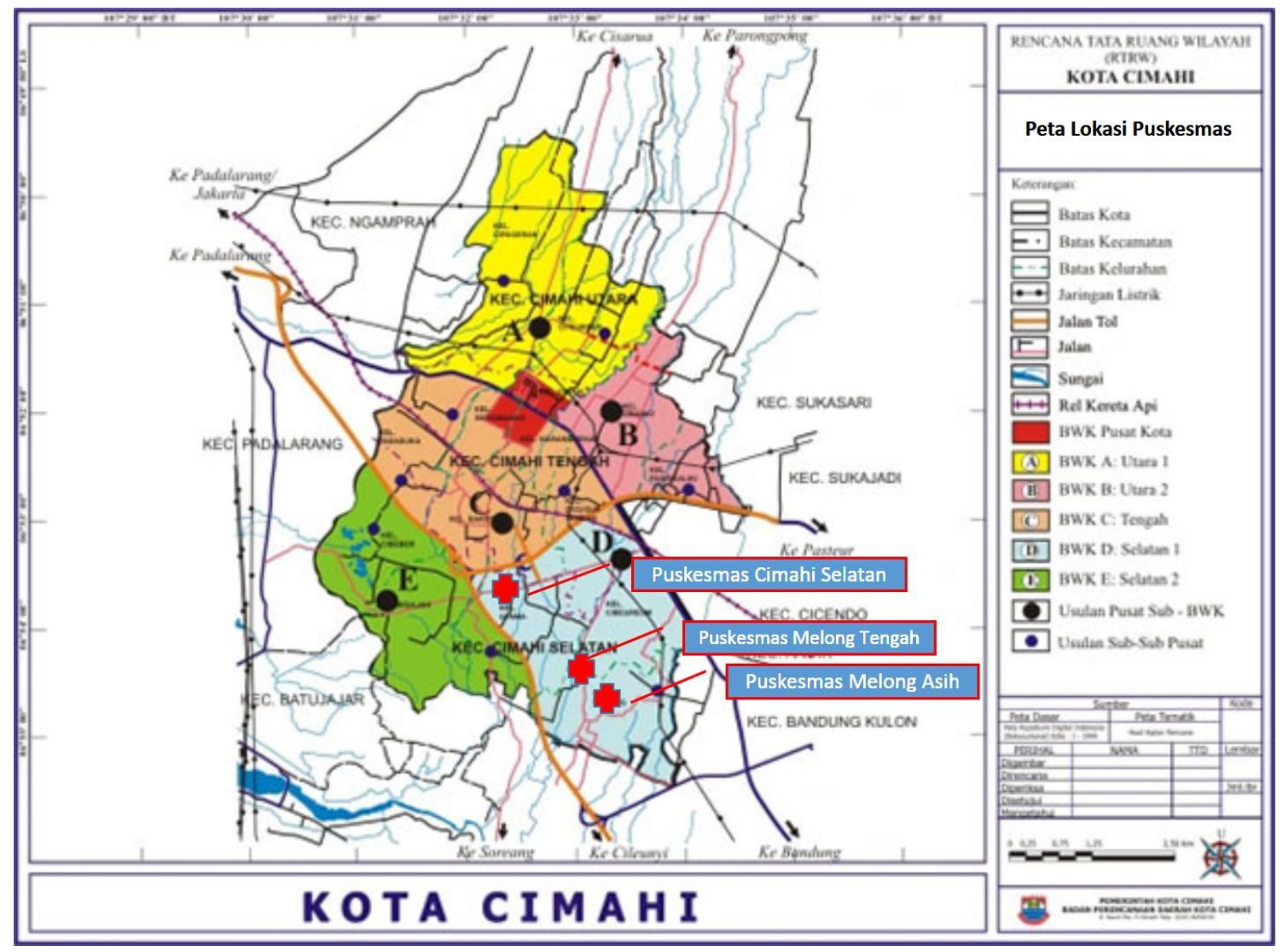

\section{Maksud dan tujuan}

Gambar 1. Peta Lokasi Puskesmas

Maksud dari penelitian ini adalah untuk mengevaluasi kualitas udara di 3 lokasi Puskesmas di Kota Cimahi Provinsi Jawa Barat.

Adapun tujuannya adalah:

1. Menguji parameter kualitas udara meliputi gas dan partikulat yakni nitrogen dioksida $\left(\mathrm{NO}_{2}\right)$, sulfur dioksida $\left(\mathrm{SO}_{2}\right)$, karbon monoksida $(\mathrm{CO})$, oksidan $\left(\mathrm{O}_{3}\right)$, dan partikulat (TSP).

2. Menganalisa tingkat pencemar udara di 3 lokasi Puskesmas.

\section{Lokasi dan waktu penelitian}

Penelitian dilakukan di 3 lokasi Puskesmas di Kota Cimahi Jawa Barat yakni Puskesmas Melong Asih, Puskesmas Melong Tengah dan Puskesmas Cimahi Selatan. Penelitian dilakukan pada periode Juni-Agustus 2014. 


\section{METODELOGI PENELITIAN}

Metodelogi yang digunakan dalam pelaksanaan penelitian ini adalah pengukuran kualitas udara langsung di lokasi penelitan bekerja sama dengan PDAM Tirta Wening Kota Bandung. Parameter kualitas udara yang diukur meliputi gas dan partikulat antara lain nitrogen dioksida $\left(\mathrm{NO}_{2}\right)$, sulfur dioksida $\left(\mathrm{SO}_{2}\right)$, karbon monoksida $(\mathrm{CO})$, oksidan $\left(\mathrm{O}_{3}\right)$, dan partikulat (TSP). Pengukuran dilakukan pada waktu siang hari sebanyak satu kali pengukuran.

Pengukuran nitrogen dioksida $\left(\mathrm{NO}_{2}\right)$, sulfur dioksida $\left(\mathrm{SO}_{2}\right)$, oksidan $\left(\mathrm{O}_{3}\right)$, dan partikulat (TSP) menggunakan peralatan tabung dan impinger, sementara untuk karbon monoksida (CO) menggunakan CO Analyzer dengan metode direct reading.

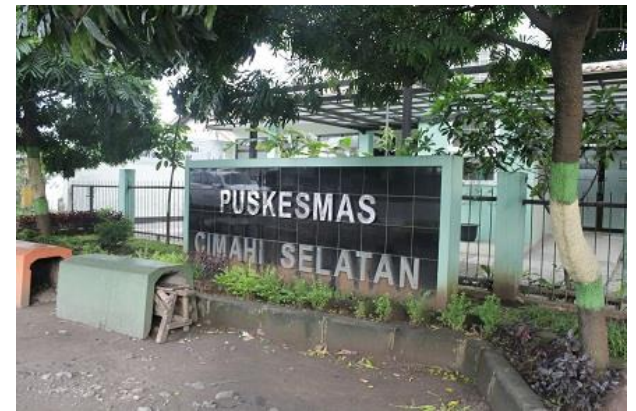

a. Tampak Depan Puskesmas Cimahi Selatan

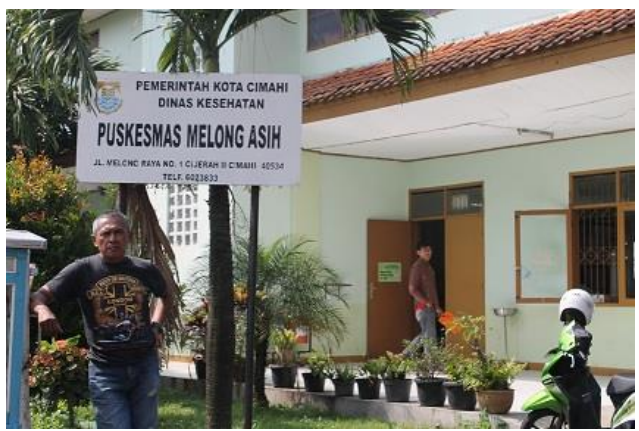

c. Tampak Depan Puskesmas Melong Asih

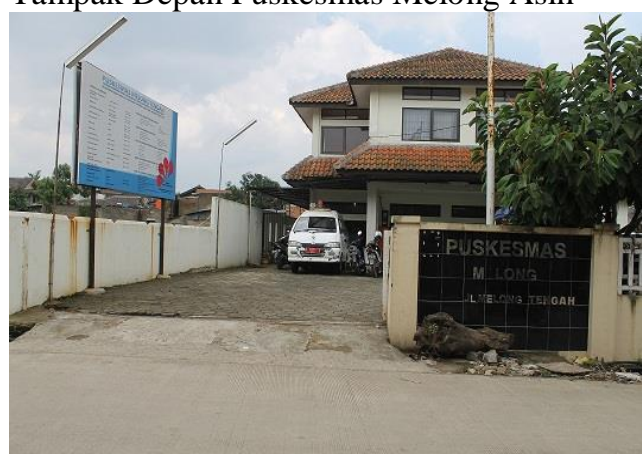

e. Tampak Depan Puskesmas Melong Tengah

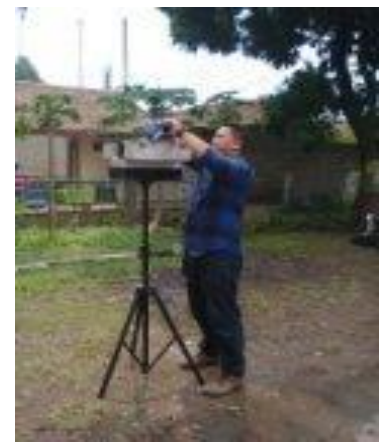

b. Pengukuran Udara di Puskesmas Cimahi

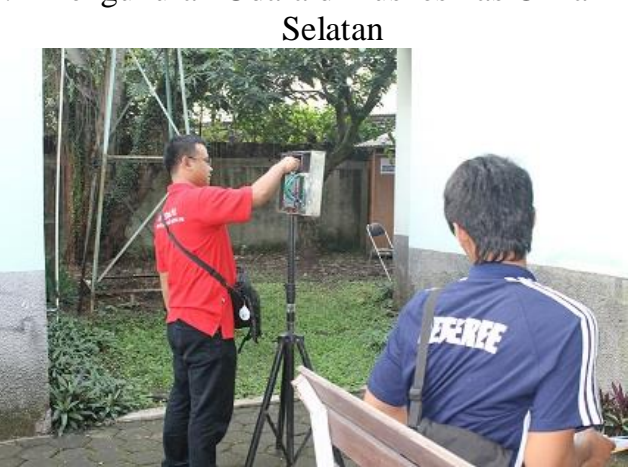

d. Pengukuran Udara di Puskesmas Melong Asih

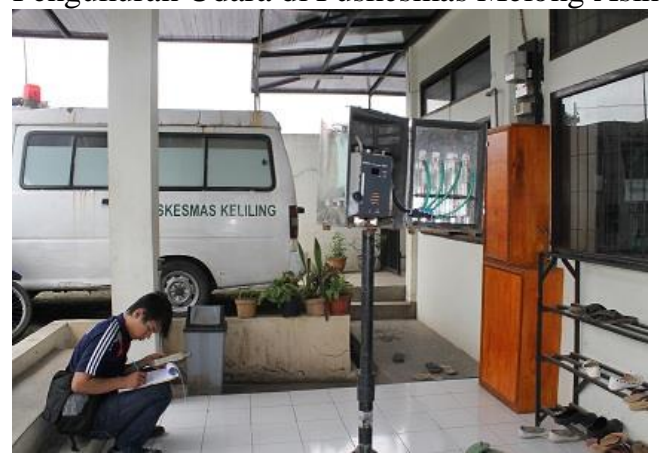

f. Pengukuran Udara di Puskesmas Melong Tengah

Gambar 1. Pengukuran Kualitas Udara 


\section{ANALISIS, HASIL DAN PEMBAHASAN}

\section{Hasil Penelitian}

Kualitas udara yang dianalisis berasal dari udara ambient di lokasi Puskesmas. Parameter yang diuji meliputi gas dan partikulat antara lain nitrogen dioksida $\left(\mathrm{NO}_{2}\right)$, sulfur dioksida $\left(\mathrm{SO}_{2}\right)$, karbon monoksida $(\mathrm{CO})$, oksidan $\left(\mathrm{O}_{3}\right)$, dan partikulat (TSP). Berikut adalah hasil analisa parameter kualitas udara dari 3 lokasi Puskesmas.

Tabel 1. Hasil Analisa Kualitas Udara di Puskesmas Cimahi Selatan

\begin{tabular}{clcccc} 
NO & PARAMETER & SATUAN & $\begin{array}{c}\text { BAKU } \\
\text { MUTU }\end{array}$ & $\begin{array}{c}\text { HASIL } \\
\text { PENGUJIAN }\end{array}$ & METODA ACUAN \\
\hline 1 & Nitrogen Dioksida $\left(\mathrm{NO}_{2}\right)$ & $\mu \mathrm{g} / \mathrm{Nm}^{3}$ & 400 & $<10$ & SNI 19-7119.2 -2005 \\
2 & Sulfur Dioksida $\left(\mathrm{SO}_{2}\right)$ & $\mu \mathrm{g} / \mathrm{Nm}^{3}$ & 900 & $<17,15$ & SNI 19-7119.7-2005 \\
3 & Karbon Monoksida $(\mathrm{CO})$ & $\mu \mathrm{g} / \mathrm{Nm}^{3}$ & 30.000 & $<1.145$ & Direct Reading \\
4 & Oksidan $\left(\mathrm{O}_{3}\right)$ & $\mu \mathrm{g} / \mathrm{Nm}^{3}$ & 235 & $<15,61$ & SNI 19-7119.8 -2005 \\
5 & Partikulat $(\mathrm{TSP})$ & $\mu \mathrm{g} / \mathrm{Nm}^{3}$ & 230 & 1,09 & SNI 19-7119.3-2005 \\
\hline
\end{tabular}

* Peraturan Pemerintah No. 41 Tahun 1999 tentang pengendalian pencemaran udara.

Sumber: Laboratorium PDAM Tirta Wening Kota Bandung, 2014

Berdasarkan hasil analisis laboratorium untuk udara dari Puskesmas Cimahi Selatan kualitas udaranya masih memenuhi baku mutu baik gas dan partikulat, hal ini terlihat dari nilai hasil uji untuk Nitrogen Dioksida $\left(\mathrm{NO}_{2}\right)$ adalah $<10 \mu \mathrm{g} / \mathrm{Nm}^{3}$ sementara baku mutu adalah $400 \mu \mathrm{g} / \mathrm{Nm}^{3}$, nilai uji Sulfur Dioksida $\left(\mathrm{SO}_{2}\right)$ diperoleh $<17,15$ $\mu \mathrm{g} / \mathrm{Nm}^{3}$ (baku mutu $\mathrm{SO}_{2}=900 \mu \mathrm{g} / \mathrm{Nm}^{3}$ ), nilai uji Karbon Monoksida (CO) diperoleh $<1.145 \mu \mathrm{g} / \mathrm{Nm}^{3}$ (baku mutu $\mathrm{CO}=30.000 \mu \mathrm{g} / \mathrm{Nm}^{3}$ ), nilai uji Oksidan $\left(\mathrm{O}_{3}\right)$ diperoleh $<15,61 \mu \mathrm{g} / \mathrm{Nm}^{3}$ (baku mutu=235 $\mu \mathrm{g} / \mathrm{Nm}^{3}$ ), sementara partikulat (TSP) diperoleh hasil $1,09 \mu \mathrm{g} / \mathrm{Nm}^{3}$ (baku mutu TSP=230 $\mu \mathrm{g} / \mathrm{Nm}^{3}$ ).

Tabel 2. Hasil Analisa Kualitas Udara di Puskesmas Melong Asih

\begin{tabular}{clcccc} 
NO & \multicolumn{1}{c}{ PARAMETER } & SATUAN & $\begin{array}{c}\text { BAKU } \\
\text { MUTU } *\end{array}$ & $\begin{array}{c}\text { HASIL } \\
\text { PENGUJIAN }\end{array}$ & METODA ACUAN \\
\hline 1 & Nitrogen Dioksida $\left(\mathrm{NO}_{2}\right)$ & $\mu \mathrm{g} / \mathrm{Nm}^{3}$ & 400 & 11,56 & SNI 19-7119.2 -2005 \\
2 & Sulfur Dioksida $\left(\mathrm{SO}_{2}\right)$ & $\mu \mathrm{g} / \mathrm{Nm}^{3}$ & 900 & 20,03 & SNI 19-7119.7 -2005 \\
3 & Karbon Monoksida $(\mathrm{CO})$ & $\mu \mathrm{g} / \mathrm{Nm}^{3}$ & 30.000 & $<1.145$ & Direct Reading \\
4 & Oksidan $\left(\mathrm{O}_{3}\right)$ & $\mu \mathrm{g} / \mathrm{Nm}^{3}$ & 235 & $<15,61$ & SNI 19-7119.8 -2005 \\
5 & Partikulat $(\mathrm{TSP})$ & $\mu \mathrm{g} / \mathrm{Nm}^{3}$ & 230 & 212,00 & SNI 19-7119.3 -2005 \\
\hline
\end{tabular}

* Peraturan Pemerintah No. 41 Tahun 1999 tentang pengendalian pencemaran udara. Sumber: Laboratorium PDAM Tirta Wening Kota Bandung, 2014

Berdasarkan hasil analisis laboratorium untuk udara dari Puskesmas Melong Asih kualitas udaranya masih memenuhi baku mutu untuk semua parameter gas, walaupun untuk partikulat (TSP), nilai hasil uji mendekati baku mutu, yakni untuk partikulat (TSP) diperoleh nilai $212 \mu \mathrm{g} / \mathrm{Nm}^{3}$ (baku mutu TSP=230 $\mu \mathrm{g} / \mathrm{Nm}^{3}$ ). Sementara untuk hasil uji Nitrogen Dioksida $\left(\mathrm{NO}_{2}\right)$ adalah $11,56 \mu \mathrm{g} / \mathrm{Nm}^{3}$ sementara baku mutu adalah $400 \mu \mathrm{g} / \mathrm{Nm}^{3}$, nilai uji Sulfur Dioksida $\left(\mathrm{SO}_{2}\right)$ diperoleh $20,03 \mu \mathrm{g} / \mathrm{Nm}^{3}$ (baku mutu $\mathrm{SO}_{2}=900 \mu \mathrm{g} / \mathrm{Nm}^{3}$ ), nilai uji Karbon Monoksida (CO) diperoleh $<1.145 \mu \mathrm{g} / \mathrm{Nm}^{3}$ (baku mutu $\mathrm{CO}=30.000 \mu \mathrm{g} / \mathrm{Nm}^{3}$ ), dan nilai uji Oksidan $\left(\mathrm{O}_{3}\right)$ diperoleh $<15,61$ $\mu \mathrm{g} / \mathrm{Nm}^{3}$ (baku mutu=235 $\mu \mathrm{g} / \mathrm{Nm}^{3}$ ). 
Tabel 3. Hasil Analisa Kualitas Udara di Puskesmas Melong Tengah

\begin{tabular}{rlcccc}
\hline \multirow{2}{*}{ NO } & PARAMETER & SATUAN & BAKU & HASIL \\
& MUENGUJIAN & METODA ACUAN \\
\hline 1 & Nitrogen Dioksida $\left(\mathrm{NO}_{2}\right)$ & $\mu \mathrm{g} / \mathrm{Nm}^{3}$ & 400 & 12,78 & SNI 19-7119.2 -2005 \\
2 & Sulfur Dioksida $\left(\mathrm{SO}_{2}\right)$ & $\mu \mathrm{g} / \mathrm{Nm}^{3}$ & 900 & 23,72 & SNI 19-7119.7 -2005 \\
3 & Karbon Monoksida $(\mathrm{CO})$ & $\mu \mathrm{g} / \mathrm{Nm}^{3}$ & 30.000 & $<1.145$ & Direct Reading \\
4 & Oksidan $\left(\mathrm{O}_{3}\right)$ & $\mu \mathrm{g} / \mathrm{Nm}^{3}$ & 235 & $<15,61$ & SNI 19-7119.8 -2005 \\
5 & Partikulat $(T S P)$ & $\mu \mathrm{g} / \mathrm{Nm}^{3}$ & 230 & 180,00 & SNI 19-7119.3 -2005 \\
\hline * Peraturan Pemerintah No. 41 Tahun 1999 tentang pengendalian pencemaran udara. \\
Sumber: Laboratorium PDAM Tirta Wening Kota Bandung, 2014
\end{tabular}

Berdasarkan hasil analisis laboratorium untuk udara dari Puskesmas Melong Tengah kualitas udaranya masih memenuhi baku mutu, dengan nilai partikulat (TSP) merupakan nilai hasil uji tertinggi dari kelima parameter uji, nilai partikulat (TSP) diperoleh nilai $180 \mu \mathrm{g} / \mathrm{Nm}^{3}$ (baku mutu TSP=230 $\mu \mathrm{g} / \mathrm{Nm}^{3}$ ). Sementara untuk hasil uji parameter gas, semua nilai hasil uji jauh di bawah baku mutu, Nitrogen Dioksida $\left(\mathrm{NO}_{2}\right)$ adalah $12,78 \mu \mathrm{g} / \mathrm{Nm}^{3}$ sementara baku mutu adalah $400 \mu \mathrm{g} / \mathrm{Nm}^{3}$, nilai uji Sulfur Dioksida $\left(\mathrm{SO}_{2}\right.$ ) diperoleh $23,72 \mu \mathrm{g} / \mathrm{Nm}^{3}$ (baku mutu $\mathrm{SO}_{2}=900 \mu \mathrm{g} / \mathrm{Nm}^{3}$ ), nilai uji Karbon Monoksida $(\mathrm{CO})$ diperoleh $<1.145 \mu \mathrm{g} / \mathrm{Nm}^{3}$ (baku mutu $\mathrm{CO}=30.000$ $\mu \mathrm{g} / \mathrm{Nm}^{3}$ ), dan nilai uji Oksidan $\left(\mathrm{O}_{3}\right)$ diperoleh $<15,61 \mu \mathrm{g} / \mathrm{Nm}^{3}$ (baku mutu=235 $\mu \mathrm{g} / \mathrm{Nm}^{3}$ ).

Jika dibandingkan nilai hasil uji parameter gas dan partikulat dari ketiga lokasi Puskesmas, maka untuk parameter gas, nilai uji terkecil terdapat di Puskesmas Cimahi Selatan, kemudian Puskesmas Melong Asih dan terakhir Puskesmas Melong Tengah. Sementara nilai parameter partikulat terkecil terdapat pada Puskesmas Cimahi Selatan, kemudian Puskesmas Melong Tengah dan terakhir Puskesmas Melong Asih, seperti terlihat pada tabel komparasi berikut:

Tabel 4. Hasil Analisa Kualitas Udara di 3 Lokasi Puskesmas

\begin{tabular}{|c|c|c|c|c|c|c|}
\hline No & Parameter & Satuan & Baku Mutu* & $\begin{array}{l}\text { Puskesmas } \\
\text { Cimahi } \\
\text { Selatan }\end{array}$ & $\begin{array}{l}\text { Puskesmas } \\
\text { Melong Asih }\end{array}$ & $\begin{array}{c}\text { Puskesmas } \\
\text { Melong } \\
\text { Tengah }\end{array}$ \\
\hline 1 & $\begin{array}{l}\text { Nitrogen Dioksida } \\
\left(\mathrm{NO}_{2}\right)\end{array}$ & $\mu \mathrm{g} / \mathrm{Nm}^{3}$ & 400 & $<10$ & 11,56 & 12,78 \\
\hline 2 & Sulfur Dioksida $\left(\mathrm{SO}_{2}\right)$ & $\mu \mathrm{g} / \mathrm{Nm}^{3}$ & 900 & $<17,15$ & 20,03 & 23,72 \\
\hline 3 & $\begin{array}{l}\text { Karbon Monoksida } \\
\text { (CO) }\end{array}$ & $\mu \mathrm{g} / \mathrm{Nm}^{3}$ & 30.000 & $<1.145$ & $<1.145$ & $<1.145$ \\
\hline $\begin{array}{l}4 \\
5\end{array}$ & $\begin{array}{l}\text { Oksidan }\left(\mathrm{O}_{3}\right) \\
\text { Partikulat (TSP) }\end{array}$ & $\begin{array}{l}\mu \mathrm{g} / \mathrm{Nm}^{3} \\
\mu \mathrm{g} / \mathrm{Nm}^{3}\end{array}$ & $\begin{array}{l}235 \\
230\end{array}$ & $\begin{array}{c}<15,61 \\
1,09\end{array}$ & $\begin{array}{l}<15,61 \\
212,00\end{array}$ & $\begin{array}{l}<15,61 \\
180,00\end{array}$ \\
\hline
\end{tabular}

* Peraturan Pemerintah No. 41 Tahun 1999 tentang pengendalian pencemaran udara.

Sumber: Laboratorium PDAM Tirta Wening Kota Bandung, 2014

\section{Pembahasan Hasil Analisis}

Hasil penelitian menunjukkan bahwa semua parameter udara gas dan partikulat yang diuji yakni nitrogen dioksida $\left(\mathrm{NO}_{2}\right)$, sulfur dioksida $\left(\mathrm{SO}_{2}\right)$, karbon monoksida $(\mathrm{CO})$, oksidan $\left(\mathrm{O}_{3}\right)$, dan partikulat (TSP) pada 3 lokasi Puskesmas di Kota Cimahi masih memenuhi baku mutu udara ambient berdasarkan Peraturan Pemerintah No. 41 Tahun 1999 tentang pengendalian pencemaran udara. Jika melihat nilai uji parameter gas dan udara dari ketiga Lokasi Puskesmas, diperoleh nilai yang berbeda-beda untuk parameter Nitrogen Dioksida $\left(\mathrm{NO}_{2}\right)$, Sulfur Dioksida $\left(\mathrm{SO}_{2}\right)$ dan partikulat (TSP), sementara nilai hasil uji parameter Karbon Monoksida (CO) dan Oksidan $\left(\mathrm{O}_{3}\right)$ diperoleh nilai yang sama dari ketiga lokasi.

Berdasarkan Soedomo (2001), konsentrasi pencemar udara di atmosfer dipengaruhi oleh faktor difusi. Faktor difusi berhubungan dengan struktur lingkungan udara, sedangkan faktor lainnya berhubungan dengan emisi yang dikeluarkan oleh kegiatan. Nitrogen Dioksida $\left(\mathrm{NO}_{2}\right)$ adalah pencemar udara yang termasuk golongan oksida nitrogen. Bagian terbesar oksida nitrogen yang terbentuk di daerah perkotaan yang paling utama adalah senyawa NO (nitric oxide). 
NO diemisikan dalam jumlah yang cukup besar ke atmosfer. $\mathrm{NO}_{2}$ diemisikan dari pembuangan pembakaran (kombusi) pada temperatur tinggi, sebagai hasil dari reaksi nitrogen dengan oksigen. Industri dan kendaraan bermotor merupakan aktivitas utama yang mengemisikan senyawa $\mathrm{NO}_{2}$. Selain itu, $\mathrm{NO}_{2}$ juga dihasilkan dari aktivitas alam seperti metabolisme bakterial. Berdasarkan hasil penelitian, konsentrasi $\mathrm{NO}_{2}$ dari ketiga lokasi diperoleh $<13 \mu \mathrm{g} / \mathrm{Nm}^{3}$. Berdasarkan penelitian Tao, dkk (2014), konsentrasi $\mathrm{NO}_{2}$ yang diketahui berbahaya terhadap kesehatan adalah $>31 \mu \mathrm{g} / \mathrm{Nm}^{3}$. Nilai ini sudah dapat menyebabkan gangguan sistem pernafasan. Sehingga dapat disimpulkan bahwa konsentrasi $\mathrm{NO}_{2}$ di ketiga lokasi Puskesmas tidak berdampak negatif terhadap kesehatan.

Sulfur Dioksida $\left(\mathrm{SO}_{2}\right)$ merupakan pencemar udara golongan oksida sulfur. Oksida sulfur merupakan pencemar yang paling umum, terutama ditimbulkan akibat pembakaran bahan bakar fosil. Sulfur dioksida merupakan bagian yang paling dominan, sehingga oksida sulfur biasanya diukur sebagai sulfur dioksida (Soedomo, 2001). Berdasarkan hasil penelitian, konsentrasi $\mathrm{SO}_{2}$ dari ketiga lokasi diperoleh $<24 \mu \mathrm{g} / \mathrm{Nm}^{3}$. Berdasarkan penelitian Tao, dkk (2014), konsentrasi $\mathrm{SO}_{2}$ yang diketahui berbahaya terhadap kesehatan adalah $>61 \mu \mathrm{g} / \mathrm{Nm}^{3}$.

Nilai ini sudah dapat menyebabkan gangguan sistem pernafasan. Sehingga dapat disimpulkan bahwa konsentrasi $\mathrm{SO}_{2}$ di ketiga lokasi Puskesmas tidak berdampak negatif terhadap kesehatan.

Karbon Monoksida (CO) merupakan pencemar udara yang paling besar dan umum dijumpai. Sebagian besar $\mathrm{CO}$ terbentuk akibat proses pembakaran bahan-bahan karbon yang digunakan sebagai bahan bakar, secara tidak sempurna. Semua aktivitas yang melibatkan pembakaran bahan-bahan organik merupakan sumber karbon monoksida. CO juga dapat terbentuk dari proses alami (Soedomo, 2001). Berdasarkan hasil penelitian, konsentrasi CO dari ketiga lokasi diperoleh $<1.145 \mu \mathrm{g} / \mathrm{Nm}^{3}$. Efek yang membahayakan manusia telah diamati pada paparan $\mathrm{CO}$ pada konsentrasi 12.000 sampai $17.000 \mu \mathrm{g} / \mathrm{Nm}^{3}$. Pengaruh kesehatan ini terdiri atas tekanan fisiologikal, terutama pada penderita penyakit jantung, keracunan darah, dan sebagainya (Soedomo, 2001). Karena nilai uji paremeter CO masih dibawah $1.145 \mu \mathrm{g} / \mathrm{Nm} 3$, sehingga dapat disimpulkan bahwa konsentrasi CO di ketiga lokasi Puskesmas tidak berdampak negatif terhadap kesehatan.

Ozon $\left(\mathrm{O}_{3}\right)$ merupakan pencemar udara golongan oksidan. Produk reaksi atmosferik antra oksida nitrogen dengan hidrokarbon, yang diinisiasi oleh sinar matahari, disebut oksidan fotokimia. Ozon merupakan senyawa yang paling dominan. Konsentrasi atmosferik biasanya dinyatakan sebagai Ozon. Oksida fotokimia dapat ditemui disetiap tempat dimana terdapat oksida nitrogen dan hydrogen yang berinteraksi di bawah radiasi sinar matahari (Soedomo, 2001). Berdasarkan hasil penelitian, konsentrasi $\mathrm{O}_{3}$ dari ketiga lokasi diperoleh $<15,61 \mu \mathrm{g} / \mathrm{Nm}^{3}$. Peneltian yang telah dilakukan Dai dkk (2015), didapatkan konsentrasi rata-rata $\mathrm{O}_{3}$ yang menyebabkan kematian karena gangguan jantung adalah $>65 \mu \mathrm{g} / \mathrm{Nm}^{3}$. Karena nilai uji paremeter $\mathrm{O}_{3}$ masih dibawah 15,61 $\mu \mathrm{g} / \mathrm{Nm} 3$, sehingga dapat disimpulkan bahwa konsentrasi $\mathrm{O}_{3}$ di ketiga lokasi Puskesmas tidak berdampak negatif terhadap kesehatan.

Partikulat yang diukur dalam penelitian ini adalah TSP (Total Suspended Particulate). TSP terdiri atas partikulat padat dan cair yang berukuran dari 100 mikron hingga kurang dari 0,01 mikron (Soedomo, 2001). Kandungan konsentasi yang terukur dari penelitian adalah gabungan dari semua jenis partikel, padat dan cair. Hampir semua jenis aktivitas manusia akan mengeluarkan emisi partikulat ke udara ambien. Dari hasil penelitian, diperoleh konsentrasi partikulat (TSP) terkecil pada Puskesmas Cimahi Selatan sebesar 1,09 $\mu \mathrm{g} / \mathrm{Nm}^{3}$, kemudian kemudian Puskesmas Melong Tengah sebesar $180 \mu \mathrm{g} / \mathrm{Nm}^{3}$ dan terakhir Puskesmas Melong Asih sebesar $212 \mu \mathrm{g} / \mathrm{Nm}^{3}$.Berdasarkan Peraturan Pemerintah No. 41 Tahun 1999 tentang pengendalian pencemaran udara, ketiga nilai hasil uji tersebut masih memenuhi baku mutu (baku mutu TSP $=230 \mu \mathrm{g} / \mathrm{Nm}^{3}$ ), namun demikian, beberapa penelitian membuktikan bahwa konsentrasi partikulat untuk $\mathrm{PM}_{2,5}$ dengan konsentrasi $24,8 \mu \mathrm{g} / \mathrm{Nm}^{3}$ telah dapat menyebabkan gangguan pernafasan asthma, $\mathrm{PM}_{2,2-10}$ dengan konsentrasi 22,8 $\mu \mathrm{g} / \mathrm{Nm}^{3}$, dan $\mathrm{PM}_{10}$ dengan konsentrasi $50,8 \mu \mathrm{g} / \mathrm{Nm}^{3}$ juga menimbulkan resiko asthma (Kim dkk, 2015). Penelitian lain menyebutkan bahwa konsentrasi $\mathrm{PM}_{2,5}$ sebesar $55 \mu \mathrm{g} / \mathrm{Nm}^{3}$ dan $\mathrm{PM}_{10}$ sebesar 92 $\mu \mathrm{g} / \mathrm{Nm}^{3}$ telah dapat menyebabkan kematian karena gangguan jantung (Dai dkk, 2015). $\mathrm{PM}_{10}$ dengan konsentrasi minimum sebesar $84 \mu \mathrm{g} / \mathrm{Nm}^{3}$ dan nilai maksimum $159 \mu \mathrm{g} / \mathrm{Nm}^{3}$ menyebabkan asthma pada anakanak (Deng dkk, 2015). Membandingkan penelitian ini dengan hasil uji laboratorium didapat partikulat (TSP) pada Puskesmas Cimahi Selatan dengan nilai konsentrasi 1,09 $\mu \mathrm{g} / \mathrm{Nm}^{3}$ dinilai tidak berdampak negatif terhadap kesehatan. Sementara partikulat (TSP) di Puskesmas Melong Asih dan Puskesmas Melong Tengah terindikasi beresiko terhadap kesehatan sehingga memerlukan perhatian khusus dalam upaya penanganan partikulat di Puskesmas Melong Asih dan Puskesmas Melong Tengah. 


\section{KESIMPULAN}

Hasil penelitian menunjukkan bahwa semua parameter udara gas dan partikulat yang diuji yakni nitrogen dioksida $\left(\mathrm{NO}_{2}\right)$, sulfur dioksida $\left(\mathrm{SO}_{2}\right)$, karbon monoksida $(\mathrm{CO})$, oksidan $\left(\mathrm{O}_{3}\right)$, dan partikulat (TSP) pada 3 lokasi Puskesmas di Kota Cimahi masih memenuhi baku mutu udara ambien berdasarkan Peraturan Pemerintah No. 41 Tahun 1999 tentang pengendalian pencemaran udara. Hal ini membuktikan bahwa kondisi udara di 3 lokasi Puskesmas di Kota Cimahi memenuhi kualitas mutu sehingga dapat mendukung Puskesmas dalam upaya menjalankan fungsi penyembuhan penyakit dan pemulihan kesehatan dengan baik, namun perlu perhatian khusus dalam upaya penanganan partikulat di Puskesmas Melong Asih dan Puskesmas Melong Tengah, karena nilai konsentrasi partikulat yang diperolah cukup tinggi walaupun masih di bawah baku mutu.

\section{DAFTAR PUSTAKA}

Agrawal, M., Singh, B., Rajput, M., Marshall, F., \& Bell, J.N.B., 2003, Effect of air pollution on peri-urban agriculture: a case study, Environmental Pollution, 126, 323-329.

Cape, J.N., 2003, Effects of airborne volatile organic compounds on plants, Environmental Pollution, 122, $145-157$.

Chan, L.Y., Lau, W.L., Zou, S.C., Cao, Z.X., \& Lai, S.C., 2002, Exposure level of carbon monoxide and respirable suspended particulate in public transportation modes while commuting in urban area of Guangzhou, China, Atmospheric Environment, Volume 36, Issue 38, 5831-5840.

Dai, J., Chen,R., Meng, X., Yang, C., Zhao, Z., \& Kan, H., 2015, Ambient air pollution, temperature and out-ofhospital coronary deaths in Shanghai, China, Environmental Pollution, 203, 116-121.

Deng, Q., Lu, C., Ou, C., \& Liu, W., 2015, Effects of early life exposure to outdoor air pollution and indoor renovation on childhood asthma in China, Building and Environment, 93, 84-91.

Dockery, D.W., Pope, C.A., Xu, X., et al., 1994, An association between air pollution and mortality in six U.S. cities, N. Engl. J. Med., 329 (24), 1753-1759.

Gostin, I. N., 2009, Air Pollution Effects on the Leaf Structure of some Fabaceae Species, Notulae Botanicae Horti Agrobotanici Cluj-Napoca, 37(2), 57-63.

Kim, J., Kim, H., \& Kweon, J., 2015, Hourly Differences In Air Pollution On The Risk Of Asthma Exacerbation, Environmental Pollution, 203, 15-21.

Lee, J.T., Kim, H., Hong, Y.C., et al., 2000. Air Pollution and Daily Mortality in Seven Major Cities Of Korea, 1991-1997. Environ. Res. A 84 (3), 247-254.

Queiroga, C.S.F., Almeida, A.S., \& Helena, L A.V., 2012, Carbon Monoxide Targeting Mitochondria, Review Article, Biochemistry Research International, Volume 2012, 1-9.

Peraturan Pemerintah No. 41 Tahun 1999 tentang Pengendalian Pencemaran Udara.

Schwartz, J., 1999, Air pollution and hospital admissions for heart disease in eight U.S. Counties, Epidemiology, 10 (1), 17-22.

Soedomo, M., 2001, Pencemaran Udara, Penerbit ITB, Bandung.

Tao, Y., Shengquan Mi, Shuhong Z., Shigong W., \& Xiaoyun X., 2014, Air pollution and hospital admissions for respiratory diseases in Lanzhou, China, Environmental Pollution, 185,196-201.

Vadveru, K.P., Ohara, T., \& Justice, K., 2014, Air pollution in Asia, Editorial, Environmental Pollution, 195, $233-$ 235.

Yang, C.Y., Chang, C.C., Chuang, H.Y., et al., 2004, Relationship Between Air Pollution and Daily Mortality in a Subtropical City: Taipei, Taiwan, Environ. Int., 30 (4), 519-523. 